\title{
Postharvest technologies for mangosteen (Garcinia mangostana L.) conservation
}

\author{
Tecnologias pós-colheita para conservação de mangostim (Garcinia mangostana L.)
}

\author{
Maria Fernanda Pontes Penteado Moretzsohn de CASTRO ${ }^{1 \star}$, Valéria Delgado de Almeida ANJOS ${ }^{1}$, \\ Ana Carolina Bortolossi REZENDE ${ }^{1}$, Eliane Aparecida BENATO ${ }^{1}$, Silvia Regina de Toledo VALENTINI ${ }^{1}$
}

\begin{abstract}
The application of technologies to extend the postharvest life of mangosteen fruit was studied and compared to storage at $25^{\circ} \mathrm{C} / 70-75 \% \mathrm{R} . \mathrm{H}$ $\left(25^{\circ} \mathrm{C}\right.$ control treatment). The fruits were packed in expanded polystyrene (EPS) trays (5 fruits/tray). Five treatments were carried out at $13^{\circ} \mathrm{C} / 90-95 \% \mathrm{RH}$ : application of carnauba wax coating, lecithin + CMC (carboxymethyl cellulose) coating, $50 \mu \mathrm{m}$ LDPE (low density polyethylene) film coating, $13 \mu \mathrm{m} \mathrm{PVC} \mathrm{(Polyvinyl} \mathrm{chloride),} \mathrm{and} \mathrm{non-coated} \mathrm{sample}\left(13^{\circ} \mathrm{C}\right.$ control treatment). Physicochemical analyses were performed twice a week. A statistical design was completely randomized with 8 repetitions for each treatment plus the control treatment. The results were submitted to variance analysis, and the averages compared by the Tukey test at $5 \%$ probability. Among the quality parameters analyzed, more significant differences were observed for weight loss, texture, and peel moisture content. The results showed that the maximum storage period for mangosteen at $25^{\circ} \mathrm{C}$ is two weeks; while storage at $13^{\circ} \mathrm{C}$ can guarantee the conservation of this fruit for 25 days. Therefore, the treatment at $13{ }^{\circ} \mathrm{C} / 90-95 \% \mathrm{RH}$ without the use of coatings and films was more effective and economical.
\end{abstract}

Keywords: PVC (polyvinyl chloride); LDPE (low density polyethylene); carnauba wax; lecithin; CMC (carboxymethyl cellulose).

\section{Resumo}

A aplicação de tecnologias visando à extensão do período de conservação de frutos de mangostim foi estudada e comparada com o armazenamento a $25{ }^{\circ} \mathrm{C} / 70-75 \%$ U.R. Os frutos foram colocados em bandejas de poliestireno ( 5 frutos/bandeja). Foram realizados cinco tratamentos a $13{ }^{\circ} \mathrm{C} / 90-95 \%$ UR: cobertura de cera de carnaúba; cobertura com lecitina + CMC (Carboximetilcelulose); filme de PELBD (polietileno linear de baixa densidade) $50 \mu \mathrm{m}$; PVC (Policloreto de vinila), e sem nenhuma cobertura ou revestimento. Foram realizadas análises físico-químicas duas vezes por semana. O delineamento estatístico empregado foi inteiramente casualizado com oito repetições para cada tratamento. Os resultados foram submetidos à análise de variância e comparação de médias pelo teste de Tukey a 5\% de probabilidade. Entre os índices de qualidade analisados, diferenças significativas foram observadas para perda de massa, textura e teor de umidade da casca. Os resultados mostraram que o período de armazenamento do mangostim a $25^{\circ} \mathrm{C}$ é de duas semanas e, quando estocado a $13{ }^{\circ} \mathrm{C}$, obteve-se a conservação dos frutos por 25 dias. Conclui-se, desse modo, que o tratamento a $13{ }^{\circ} \mathrm{C} / 90-95 \% \mathrm{UR}$ sem o uso de coberturas e filmes foi o melhor e o mais econômico.

Palavras-chave: PVC; PELBD; cera de carnaúba; lecitina; CMC.

\section{Introduction}

Mangosteen (Garcinia mangostana Linn.), family Clusiaceae, is considered one of the most delicious fruits of the Asian tropics. It was introduced in Brazil in 1935, and nowadays it is grown mostly in the States of Para and Bahia in an estimated area of 350 ha with an output of $300 \mathrm{t}$. The main harvest season in Para is from January to May and a shorter harvest period in August-September. In the State of Bahia, the main harvest season is from March to April and a second harvest occurs in August (SACRAMENTO et al., 2007). In order to have supply of this fruit between harvest seasons, which ranges from two to four months depending on local production, it is necessary to use postharvest techniques for the extension of mangosteen shelf life. The utilization of low temperatures, plastic films, and edible coatings are some of the options to increase the shelf life of fruits. Mangosteen fruits have a storage and marketable postharvest life of not more than one week under tropical conditions. At low temperatures $\left(9-12^{\circ} \mathrm{C}\right)$, mangosteen may have a storage life of up to four weeks (MARTIN, 1980). According to Osman and Milan (2006), at present, the best method for fruit storage is by keeping it under refrigeration. Yaacob and Tindall (1995) reported that the fruits stored in cardboard boxes at room temperature can maintain their quality for more than four weeks and that the storage of ripe fruit at temperatures from 4 to $8^{\circ} \mathrm{C}$ can prolong shelf life. These authors state that the temperature of $13^{\circ} \mathrm{C}$, however, proved to be more favourable to store and maintain the quality standard of the fruits and the ideal temperature for their transportation. Storage temperatures between 4 and $8^{\circ} \mathrm{C}$ can be used to prolong the shelf life of mangosteen, but with storage at low temperatures, the hardening of the pericarp reduces the overall consumer acceptability of the fruit due to the difficulty of

\footnotetext{
Received 12/8/2010

Accepted 28/2/2012 (004981)

${ }^{1}$ Grupo de Engenharia e Pós-Colheita, Instituto de Tecnologia de Alimentos - ITAL, Av. Brasil, 2880, Jd. Brasil, CP 139, CEP 13070-178, Campinas, SP, Brasil,

e-mail:fernanda@ital.sp.gov.br

${ }^{*}$ Corresponding author
}

DOI: http://dx.doi.org/10.1590/S0101-20612012005000103 
cutting it open (AUGUSTIN; AZUDIM, 1986). Choehom et al. (2003) verified that storage of mangosteen at $12{ }^{\circ} \mathrm{C}$ produced acceptable levels of chilling symptoms, and therefore resulted in the longest storage life (20 days). Studies to determine the extension of storage time of mangosteen fruits when packed in polyethylene (LDPE) film bags with different thicknesses at temperatures of 8 and $13^{\circ} \mathrm{C}$ were carried out by Pranamornkith, Kanlayanarat and Uthairatanakij (2003a). These authors found that, compared to non-packed fruits, the use of polyethylene film bag, regardless of thickness and temperature of storage, increased the shelf life of fruits. Fruits kept at $13^{\circ} \mathrm{C}$ and packed in LDPE film bag of 40 and $80 \mu \mathrm{m}$ had the longest retention period ( 24 days), but the thickness of $40 \mu \mathrm{m}$ maintained higher quality than that of $80 \mu \mathrm{m}$. These same authors later compared the use of $40 \mu \mathrm{m}$ LDPE with $42 \mu \mathrm{m}$ PVC (polyvinyl chloride) to prolong the preservation of the fruit at $13{ }^{\circ} \mathrm{C}$, individually and in packs of four (4). LDPE was more effective than PVC, and the package with four fruits was better than the individually packed fruits in terms of respiration inhibition, ethylene production, weight loss, shell brightness, chlorophyll cup, and firmness of the fruit. Therefore, fruits packed with LDPE had a storage period of 24 days, while those packed with PVC had a 20-day storage period. Fruits individually wrapped in LDPE or PVC lasted for 20 and 16 days, respectively. Soluble solids and acidity were not adversely affected (PRANAMORNKITH; KANLAYANARAT; UTHAIRATANAKIJ, 2003b). Edible coatings, such as carnauba wax, have also shown to be good alternatives for improving fruit storability. Wax is used to reduce mass loss (moisture) and, consequently, softening and wilting; it also gives the fruit a more shiny appearance improving its visual quality (KAPLAN, 1986). Additionally, it has an anti-mold action and minimizes skin disorders and tissue collapse close to the petiole (WAKS et al., 1985). Wax coatings increase the conservation period of fruits and vegetables because of the reduction of the transpiration rate and metabolic activity (OLIVEIRA, 1996). Hagenmaier and Baker (1994) stated that emulsions based on carnauba wax give better protection against weight loss than the shellac-based wax, oxidized polyethylene, and wood resin. Formulations containing $5 \%$ of wax decreased the softening of guava from 10 to $30 \%$ (McGUIRE; HALLMAN, 1995). The use of wax coating extended peach postharvest life (CHITARRA; CARVALHO, 1985; HAGENMAIER; BAKER, 1994). Baldwin and Wood (2006) argued that CMC (carboxymethyl cellulose)-based coatings exhibit potential for extending the shelf life of pecan kernels, but no studies have been carried out with mangosteen so far. The aim of this study was to evaluate the use of low temperature $\left(13{ }^{\circ} \mathrm{C}\right)$ alone and in combination with edible coatings and plastic films to extend mangosteen postharvest life.

\section{Material and methods}

Mangosteen (G. mangostana L.) fruit, at the reddish purple maturity state, were obtained from a plantation in Una, Bahia State, Brazil. The fruits were harvested manually, graded and packed into $21.0 \times 21.5 \times 6.5 \mathrm{~cm}$ cardboard boxes, and transported to the Institute of Food Technology (ITAL), Campinas, SP, where the experiments were performed. A completely randomized design was used with six treatments, eight repetitions, and eight evaluation periods. The fruits were packed in expanded polystyrene trays with internal dimensions of $152 \times 152 \mathrm{~mm}$, and compared to storage at $25^{\circ} \mathrm{C} / 70-75 \% \mathrm{RH}$ ( $25{ }^{\circ} \mathrm{C}$ control treatment). A total of 5 treatments were performed at $13{ }^{\circ} \mathrm{C} / 90$ to $95 \% \mathrm{RH}$ : application of carnauba wax coating (Carnauba wax), lecithin + CMC (carboxymethyl cellulose) coating, $50 \mu \mathrm{m}$ LDPE (low density polyethylene) film coating, $13 \mu \mathrm{m}$ PVC (Polyvinyl chloride), and non-coated sample. Carnauba wax (Meghwax ECF 124, Megh, Brazil) was dissolved in water to a concentration of $14 \%$. The CMC + lecithin coating was obtained after fruit immersion in a mixture made up of $0.2 \%$ lecithin and 2\% of CMC-Carboxymethylcellulose PKelco CEKOLtype 30,000. After immersion for 10 seconds, mangosteen fruits were dried under ventilation and packed in the polystyrene trays (five fruits/tray). The LDPE-film of $50 \mu \mathrm{m}$ thickness and the PVC film bag of $13 \mu \mathrm{m}$ thicknesses were used. The fruits were submitted to physicochemical analyses twice a week. Temperatures and relative humidity were monitored during storage.

\subsection{Physicochemical analyses}

Weight losses, which occurred in fruits during storage, was measured using a semi-analytical balance $(0.01 \mathrm{~g}$ precision) considering the former weight value in each analytical period. Firmness, expressed as pericarp hardness, was determined using a texture analyzer TA-TX2i (stable Microsystems) fitted with a TA-135 (cylinder with a $35 \mathrm{~mm}$ diameter). Soluble solids (SS) was determined using a hand refractometer (Atago, model N-1a Tokyo, Japan) with a scale of 0 to $32^{\circ}$ Brix. Titratable acidity was determined by titrating $10 \mathrm{~g}$ of the homogenized pulp with $0.01 \mathrm{~N} \mathrm{NaOH}$ to end point at $\mathrm{pH} 8.1$ with the results expressed as $\mathrm{g}$ of citric acid in $100 \mathrm{~g}^{-1}$ (ASSOCIATION..., 1995).The $\mathrm{pH}$ value was obtained by the potentiometer method, with a $\mathrm{pH}$ meter (blend Tecnopon, model mPA 210/mPA - 210P). Peel moisture content was determined by weighing from peel samples (from 2 to $10 \mathrm{~g}$ ) and drying them in a non-ventilated oven at $103 \pm 2{ }^{\circ} \mathrm{C}$ for three (3) hours or up to constant weight. These analyses were performed before storage and at the $8^{\text {th }}$, $14^{\text {th }}$, and $21^{\text {st }}$ day of storage.

\subsection{Identification of the main fungi causing postharvest rot}

During storage, the fruits were periodically checked for visible rot symptoms. Rotten fruits were disinfected and small fragments of damaged tissue transferred to Petri dishes containing potato dextrose agar (PDA) with oxytetracycline $\left(50 \mu \mathrm{g} . \mathrm{mL}^{-1}\right)$ culture medium and incubated in a chamber at $25^{\circ} \mathrm{C}$ under alternating light until the appearance of colonies for identification.

\subsection{Statistical analyses}

A completely randomized statistical design was used for six treatments, eight repetitions and eight evaluation periods. The results of the physicochemical analysis of the treatments were submitted to analysis of variance and their means were compared by Tukey test at $5 \%$ probability $(\mathrm{p}<0.05)$. 


\section{Results and discussion}

\subsection{Physicochemical analyses}

Weight loss

The maximum weight loss occurred in the $25^{\circ} \mathrm{C}$ control treatment. (34.4\%), while the storage at $13{ }^{\circ} \mathrm{C}$ had significant effect on reducing weight loss, independently of the treatment applied. The weight loss of the fruits in the $13{ }^{\circ} \mathrm{C}$ control treatment and carnauba wax and Lecithin + CMC treatments was of $8.9 \%$, on average; there were no significant differences among the means of the three treatments $(p<0.05)$. There were no significant differences $(p<0.05)$ between the LDPE and PVC treatments either, which showed the lowest means of weight loss at the end of storage, $1,4 \%$ on average and differed from all other treatments (Figure 1).

Application of surface coatings and wrapping fruits in polyethylene film bags (DARYONO; SABARI, 1986) reduce weight loss (CHOEHOM, 1997). In the present study, the use of LDPE and PVC films was more efficient than the use of surface coatings in reducing weight loss of mangostin fruits stored at $13{ }^{\circ} \mathrm{C}$.

\section{Peel moisture content}

The fruits in the $25^{\circ} \mathrm{C}$ control treatment had the lowest peel moisture content at the $14^{\text {th }}$ day of storage compared to the other treatments. The fruits packed in LDPE showed the highest peel moisture contents, followed by PVC and carnauba wax coating. At the $21^{\text {st }}$ day of storage; no significant differences $(\mathrm{p}<0.05)$ were observed between the moisture content of the treatments at $13^{\circ} \mathrm{C}$ and with film coating (Figure 2). Kondo et al. (2003) verified that in mangosteen stored at $7^{\circ} \mathrm{C}$ the hardening of the skin was not accompanied by moisture loss. In the present study, both the peel moisture content and firmness means began to differ significantly $(\mathrm{p}<0.05)$ from the $14^{\text {th }}$ day of storage.

\section{Firmness}

Significant differences in firmness, expressed as pericarp hardening, were observed only at the $18^{\text {th }}$ day of storage and only for the fruits in the $25^{\circ} \mathrm{C}$ control treatment at (Figure 3 ). These fruits had significant $(\mathrm{p}<0.05)$ higher values $(140 \mathrm{~N})$ than those of the other treatments, and at this period peel hardness did not allow fruit cutting. As a result, the analyses of this treatment were interrupted. Up to the $18^{\text {th }}$ day of storage, the remaining treatments showed firmness average values from $40 \mathrm{~N}$ to $47 \mathrm{~N}$. From this date on, it was observed a significant increase $(\mathrm{p}<0.05)$ in the hardness means of the fruits in the Carnauba wax treatment compared to the other treatments, so that the fruits could no be cut. The lignification process has a structural function in plants, and it often occurs as a metabolic response to the stress imposed on vegetal tissues due to the harvest and postharvest handling, ethylene, changes in temperature, loss of water, composition and gas exchange, mechanical injuries, and senescence (SIEGEL, 1993; CHITARRA; HITARRA, 2005). The respiration pattern of mangosteen resembles that of climacteric fruits; the fruits are sensitive to ethylene application, which triggers autocatalytic ethylene production (NOICHINDA, 1992). In the interval between 0 and $30^{\circ} \mathrm{C}$, respiratory rate of a product can double and even quadruple for each increase of $10{ }^{\circ} \mathrm{C}$ in the temperature, and it increases the release of energy such as heat and ethylene production in some plants requiring the application of cooling and ventilation to prolong the life of the product (KADER, 2002). The fruits in the $25^{\circ} \mathrm{C}$ control treatment had the highest firmness and weight loss values as well as the lowest peel moisture content indicating the effect of the storage temperature and ethylene on mangosteen metabolism.

\section{Total soluble solids (TSS)}

In general, few changes occurred in TSS values during storage for all treatments, and TSS ranged from 15.2 to $19.1^{\circ} \mathrm{Brix}$. At the $25^{\text {th }}$ day of storage, the fruits in the $13^{\circ} \mathrm{C}$ control treatment

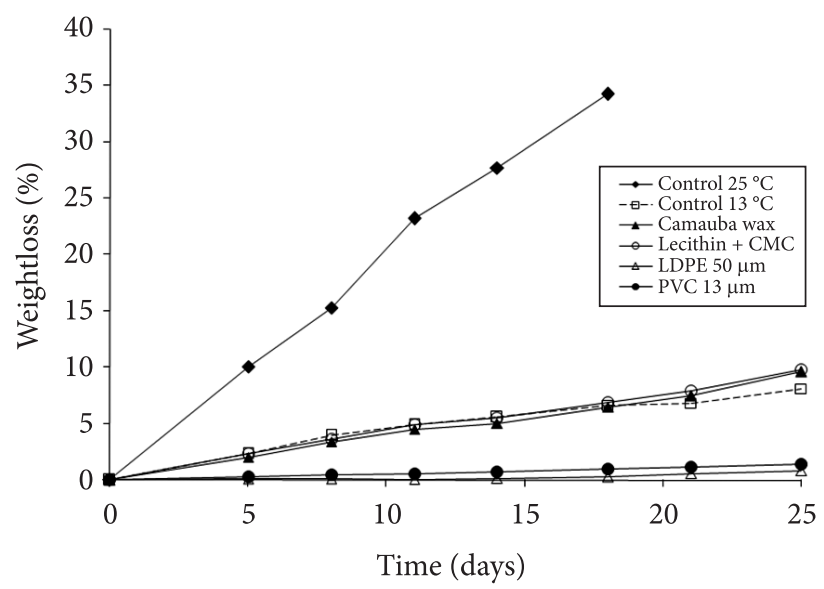

Figure 1. Weight loss means (\%) in mangosteen stored at $25^{\circ} \mathrm{C} / 75 \% \mathrm{RH}$ and at $13{ }^{\circ} \mathrm{C}$ with carnauba wax, lecithin + CMC , polyethylene, polyvinyl chloride, and no coating or film.

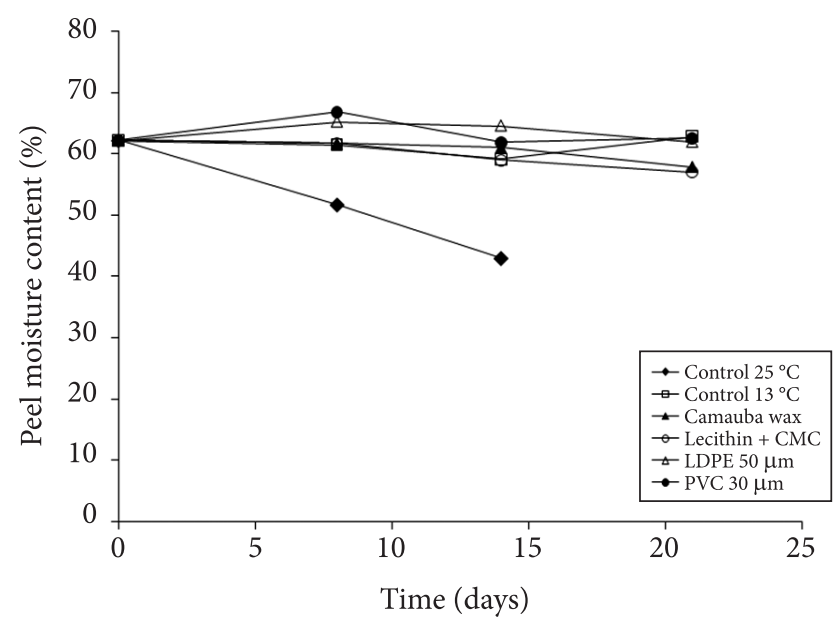

Figure 2. Peel moisture content means (\%) of mangosteen stored at $25{ }^{\circ} \mathrm{C} / 75 \% \mathrm{RH}$, and at $13{ }^{\circ} \mathrm{C}$ with carnauba wax, lecithin+CMC, polyethylene and polyvinyl chloride, and no coating or film. 
and Lecithin + CMC treatments had significant higher $(\mathrm{p}<0.05)$ TSS values compared to those of the carnauba wax (Figure 4). The fruits in the $25^{\circ} \mathrm{C}$ control treatment also presented higher TSS values compared to the means of the other treatments at the $11^{\text {th }}$ and $15^{\text {th }}$ day of storage due to weight loss. Augustin and Azudin (1986) found that the soluble solids of mangosteen stored at $8{ }^{\circ} \mathrm{C}$ varied between 17.7 and $20.4{ }^{\circ}$ Brix.

\section{Titratable acidity (TA)}

A tendency toward lower titratable acidity was observed for all treatments during storage although no significant differences ( $p<0.05$ ) were observed among the means of the six treatments. The average values ranged from $0.72 \%$ (day zero) to $0.49 \%$ ( $25^{\text {th }}$ day) (Figure 5$)$. The decrease is due to the consumption of organic acids and other chemical components by respiration and transpiration (CHITARRA; CHITARRA, 2005). Again, it was observed the temperature effect on mangosteen fruits. Those stored at $25{ }^{\circ} \mathrm{C}$ had the titratable acidity reduced in a shorter

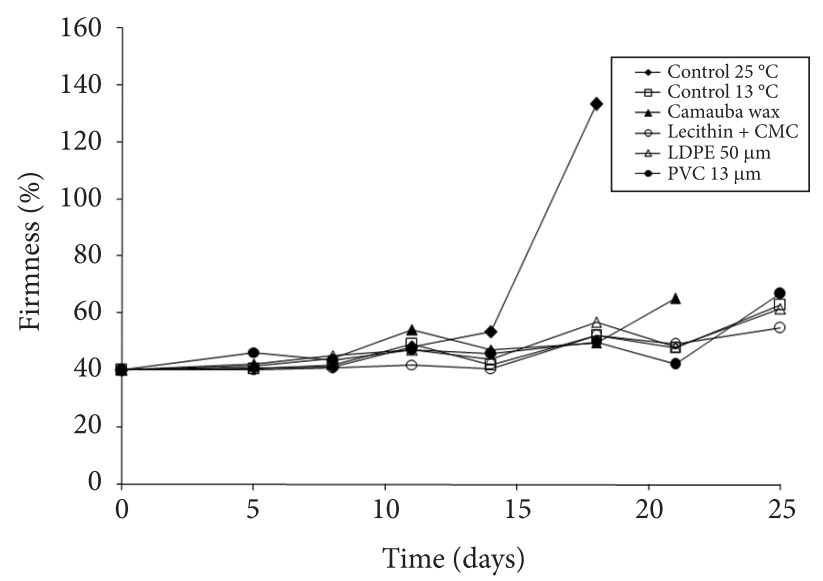

Figure 3. Firmness means (N) of mangosteen stored at $25^{\circ} \mathrm{C} / 75 \% \mathrm{RH}$ and at $13{ }^{\circ} \mathrm{C}$ with carnauba wax, lecithin + CMC, polyethylene and polyvinyl chloride, and no coating or film.

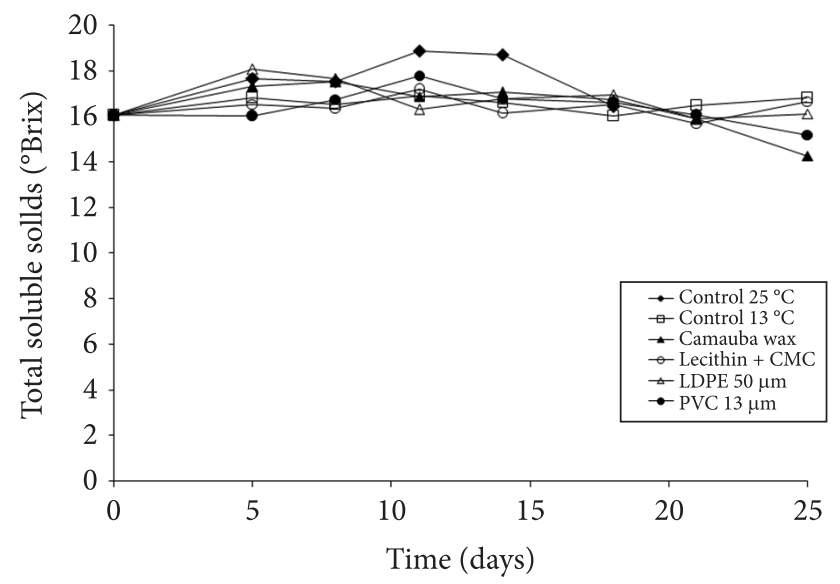

Figure 4. Total soluble solids means ( $\left.{ }^{\circ} \mathrm{Brix}\right)$ in mangosteen stored at $25{ }^{\circ} \mathrm{C} / 75 \% \mathrm{RH}$ and at $13{ }^{\circ} \mathrm{C}$ with carnauba wax, lecithin + CMC, polyethylene and polyvinyl chloride, and no coating or film. period $-0.51 \%$ at the $18^{\text {th }}$ day- compared to that of the fruits in the other treatments, which had the same value at the $25^{\text {th }}$ day.

$p H$

In general, no significant changes $(\mathrm{p}<0.05)$ were observed during storage for all treatments regarding the $\mathrm{pH}$ means (Figure 6). The variation range was from 3.2 to 3.6. The increases in $\mathrm{pH}$ did not correspond to decreases in TA.

\subsection{Postharvest rots}

During the experiment, the pathogens that caused mangosteen postharvest rot were isolated and identified as Lasiodiplodia theobromae, Pistalotiopsis sp., Penicillium sp. and Phomopsis sp. Except for this last one, other fungi such as Diplodia gossypina, Pestalotia sp., Gloesporium sp. and Rhyzopus nigricans had beenreported by Morton (1987) as causing damage during mangosteen storage.

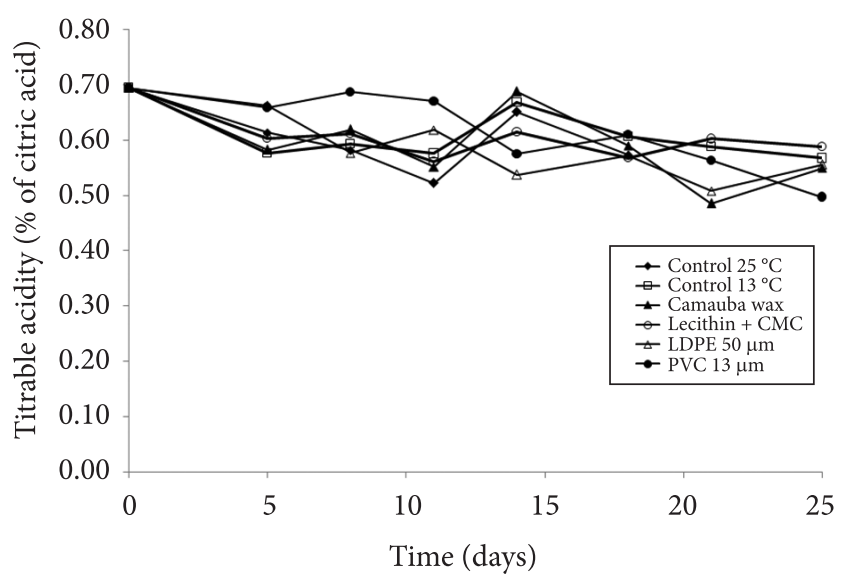

Figure 5. Titratable acidity means (TA)in mangosteen stored at $25{ }^{\circ} \mathrm{C} / 75 \% \mathrm{RH}$ and at $13{ }^{\circ} \mathrm{C}$ with carnauba wax, lecithin + CMC, polyethylene and polyvinyl chloride, and no coating or film.

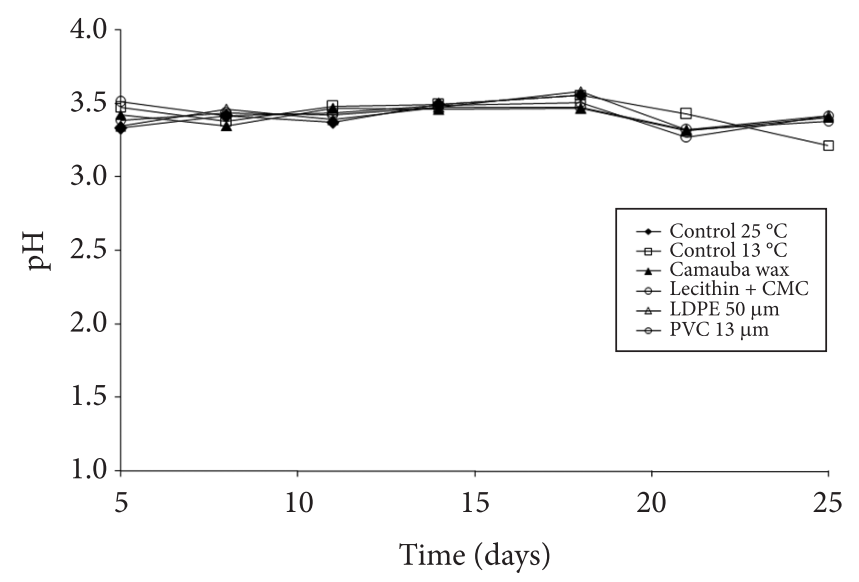

Figure 6. $\mathrm{pH}$ means in mangosteen stored at $25^{\circ} \mathrm{C} / 75 \% \mathrm{RH}$ and at $13^{\circ} \mathrm{C}$ with arnauba wax, lecithin $+\mathrm{CMC}$, polyethylene and polyvinyl chloride, and no coating or film. 


\section{Conclusions}

In general, refrigerated storage of mangosteen at $13{ }^{\circ} \mathrm{C}$ extended the shelf-life for 25 days, while those stored at $25^{\circ} \mathrm{C}$ had the shelf-life limited to 15 days. The main limiting factor was the pericarp hardening, which resulted in the increase of firmness. The edible coatings and plastic films combined with storage at $13{ }^{\circ} \mathrm{C}$ showed different results: the fruits coated with carnauba wax had the shelf-life limited to 18 days due to pericarp hardening. Coating with CMC + lecithin and packging with LDPE $50 \mu \mathrm{m}$ and PVC $13 \mu \mathrm{m}$ had no effect on mangosteen shelf-life extension when compared to the fruits stored under refrigeration without any coating and films. Considering that the use of films and coatings represents additional costs, the storage of mangosteen at $13^{\circ} \mathrm{C}$ without the use of any other method was the most effective.

\section{References}

ASSOCIATION OF OFFICIAL ANALYTICAL CHEMISTS - AOAC. Official Methods of Analysis. 16. ed. Washington: AOAC, 1995.

AUGUSTIN, M. A.; AZUDIM, M. N. Storage of mangosteen (Garcinia mangostina L.). ASEAN Food Journal, v. 2, n. 2, p. 78-80, 1986.

BALDWIN, E. A.; WOOD, B. Use of edible coating to preserve pecans at room temperature. Horticultural Science, v. 41, n.1, p. 188$192,2006$.

CHITARRA, M. I. F.; CARVALHO, V. D. Frutos temperados: pêssegos, ameixas e figos. Informe Agropecuário, v. 11, n. 125, p. 56-66, 1985.

CHITARrA, A. B.; CHITARRA,M. I. F. Pós-colheita de frutas e hortaliças: fisiologia e manuseio. 2. ed. Lavras: UFLA, 2005. 785 p.

CHOEHOM, R. Effect of waxing and plant growth regulators on quality and storage -life of mangosteen (Garcinia mangostana L.) fruit during cold storage. Bangkok: Kasetsart University, Department of Horticulture, 1997. Graduate Special Problem.

CHOEHOM, R.; KETSA, S.; VAN DOORN, W. G. Chilling injury in mangosteen fruit. Journal of Horticultural Science and Biotechnology, v. 78, n. 4, p. 559-562, 2003.

DARYONO, M.; SABARI, S. The practical method of harvest time on mangosteen fruit and its characteristics in storage. Bulletin Penelitian Hortikultura, n. 14, p. 38-44, 1986.

HAGENMAIER, R. D.; BAKE, R. A. Wax micro emulsions and emulsions as citrus coating. Journal of Agricultural and Food Chemistry, n. 42, p. 899-902, 1994. http://dx.doi.org/10.1021/ jf00040a012

KAPLAN. H. J. Washing waxing and color-adding. In: WARDOWSKI, W. F.; NAGY, S.; GRIERSON, W. (Eds.). Fresh Citrus Fruit. New York: AVI Publishing, 1986. p. 379-395.

KADER, A. Postharvest biology and technology: an overview. In: KADER, A.A. (Ed.). Postharvest Technology of Horticultural
Crops. Oakland: Regents of the University of California Division of Agricultural and Natural Resources, 2002. p. 39-48.

KONDO, S. et al. Relationship between ABA and chilling injury in mangosteen fruit treated with spermine. Plant Growth Regulation. v. 39, n. 2, p. 119-124, 2003. http://dx.doi. org/10.1023/A:1022521623721

MARTIN, F. W. Durian and Mangosteen. In: NAGY, S.; SHAW, P. E. (Ed.). Tropical and subtropical fruits. Westport: AVI Publishing, 1980. p. 407-414.

McGUIRE, R. G.; HALLMAN, G. J. Coating guavas with cellulose-or carnauba-based emulsions interferes with post harvest ripening. Postharvest Biology and Technology, v. 30, n. 2, p. 294-5, 1995.

MORTON, J. F. Mangosteen. In: MORTON, J. F. Fruits of warm climates. Miami, 1987. p. 301-304.

NOICHINDA, S. Effect of modified atmosphere condition on quality and storage life of mangosteen (Garcinia mangostana L.) fruit.1992. $74 \mathrm{f}$. Thesis (Doctorate)-Kasetsart Univercity, Bangkok, 1992.

OLIVEIRA, M. A. Utilização de películas de fécula de mandioca como alternativa à cera comercial na conservação pós-colheita de frutos de goiaba (Psidium guayava) variedade Kumagai. 1996. 73 f. Dissertação (Mestrado em Ciência e Tecnologia de Alimentos)Escola Superior de Agricultura "Luiz de Queiroz", Universidade de São Paulo, Piracicaba, 1996.

OSMAN, M. B.; MILAN, A. R. Fruits for the Future - Mangosteen (Garcinia mangostana). Southampton : Southampton Centre for Underutilised Crops, 2006. 170 p.

PRANAMORNKITH, T.; KANLAYANARAT, S.; UTHAIRATANAKIJ. A. Effect of polyethylene film packaging on the storage life of mangosteen fruit (Garcinia mangostana L.). In: AUSTRALIAN POST HARVEST HORTICULTURE CONFERENCE, 2003, Brisbane. Proceedings... Brisbane, 2003a.

PRANAMORNKITH, T., KANLAYANARAT, S., UTHAIRATANAKIJ, A. Effect of polymeric films and packing methods on storage life of mangosteen fruit (Garcinia mangostana L.). In: AUSTRALIAN POST HARVEST HORTICULTURE CONFERENCE, 2003, Brisbane. Proceedings... Brisbane, 2003b.

SACRAMENTO, C. K. et al. Cultivo do Mangostim no Brasil. Revista Brasileira de Fruticultura, v. 29, n. 1, p. 195-203, 2007. http:// dx.doi.org/10.1590/S0100-29452007000100042

SIEGEL, B. Z. Plant peroxidases - an organismic perspective. Plant Growth Regulation, v. 12, p. 303-312, 1993. http://dx.doi. org/10.1007/BF00027212

YAACOB, O.; TINDALL, H. D. Mangosteen cultivation. Roma: FAO, 1995. 103 p. (Plant Production and Protection Paper, n. 129).

WAKS, J. et al. Relationship between fruit waxing and development of rots in citrus fruit during storage. Plant Disease Reporter, v. 69, n. 10, p. 869-870, 1985. http://dx.doi.org/10.1094/PD-69-869 